International Journal of Social Sciences and Humanities
Available online at http://sciencescholar.us/journal/index.php/ijssh
Vol. 2 No. 3, December 2018, pages: 45 55
e-ISSN: 2550-7001, p-ISSN: 2550-701X
http://dx.doi.org/10.29332/ijssh.v0i0.000

\title{
Pemaliq in Forest and Mountain of Sasak Community (Linguistic Anthropology)
}

\author{
Suliadi a, I Ketut Darma Laksana ${ }^{\text {b, }}$ Mahyuni c, I Wayan Simpen d, \\ Article history: Received 8 April 2018, Accepted: 30 August 2018, Published: 15 September 2018
}

\section{Correspondence Author ${ }^{\text {a }}$}

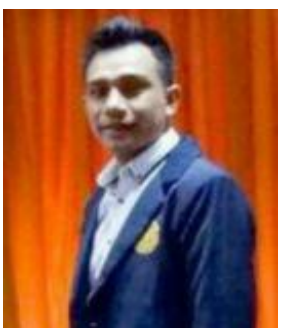

Keywords

Cultural practices;

Cultural sources;

Pemaliq expressions;

Pemaliq represent values;

Sasak bayan community;

\begin{abstract}
This short writing aims at revealing the meaning and values of pemaliq expressions that can be applied in managing and controlling life. As an effort to uncover the meaning and value of pemaliq, this study employed anthropological linguistic theory grounded in the view that pemaliq is a cultural source and as a practice of speaking. To collect the data needed, this study applied observation method to the participants of this study and in-depth interview. The data gathered were then analysed by applying ethnographic methods namely domain analysis, taxonomic analysis, component analysis, and analysis of cultural themes. The results of the analysis show that pemaliq is practiced by the Sasak Bayan community in North Lombok, West Nusa Tenggara, Indonesia in the forest and mountain environment, namely pemaliq in the realm of the okat 'words or spoken' and pemaliq in the realm of pegawean 'action'. Pemaliq okat 'word or spoken' is shown in the form of the phrase menggoaq bangsa "mentioning caste" and ngaranin sesato 'naming animals'. Meanwhile, pemaliq pegawean 'action' is realized in the form of phrases and words those are merebang kayuq 'cutting down trees', membait kayuq 'taking the woods' and nyelonong 'without permission. The production and the use of these pemaliq represent values that can be applied in human life such as (1) respect; (2) alert; (3) polite; (4) humble; (5) tolerant; (6) responsible; (7) not greedy; (8) care of the environment; (9) awareness; (10) wisdom; (11) critical knowledge; and (12) thankful.
\end{abstract}

e-ISSN: 2550-7001, p-ISSN: 2550-701X ๑ Copyright 2018. The Author. SS Journals Published by Universidad Técnica de Manabí. This is an open-access article under the CC BY-SA 4.0 license (https://creativecommons.org/licenses/by-sa/4.0/) All rights reserved.

a Doctor Candidate - Udayana University, Indonesia

b Supervisor- Udayana University, Indonesia

c Co-Supervisor 1st - Mataram University, Indonesia

d Co-Supervisor 2st - Udayana University, Indonesia 


\section{Contents}

Abstract

1. Introduction.

2. Materials and Methods.

3. Results and Discussions..

3.1 Pemaliq Okat 'Words or Spoken'.

3.2 Pemaliq Pegawean 'action'

4. Conclusion

Acknowledgements..

References.

Biography of Authors.

\section{Introduction}

Every region in Indonesia has different terms to convey the expression of prohibition. One region that has the term to express prohibition is Lombok Island which is inhabited by the Sasak tribe. The term used by this region to express prohibition is called pemaliq. Pemaliq basically comes from the word maliq meaning 'prohibition, avoidance, or taboo'. In this case, pemaliq is produced by the ancestors to prohibit themselves and members of their indigenous community from saying certain words and from taking certain actions that can endanger themselves, others, and nature. In other words, pemaliq is used as a binding rule or basic norm in living a life. It means that pemaliq is produced by ancestors for a matter that is taboo, something that is limiting or restraining oneself in acting (Freud, 2001: 31-32).

As an effort to realize the goal of pemaliq above, the ancestors weave their creative ideas in the form of expressions of prohibition. In this case, the ancestors tried to produce expressions expressing prohibitions in saying words and doing certain actions. Prohibition of saying certain words and actions illustrates the belief of the Sasak community as a producer of the influence of the danger/disaster that can be raised by prohibited matters.

Furthermore, related with this article, we will discuss pemaliq in the forest and mountain environment used by the Sasak Bayan community in North Lombok, West Nusa Tenggara, Indonesia. In this case, the use of pemaliq in forest and mountain environments is identical with mystical local community beliefs such as the belief in supernatural forces in the forest environment that can cause danger or bad nfluence to the community members who act arbitrarily, namely the people who violate pemaliq both in the form of words and actions. In addition, pemaliq used in forest and mountain environments are full of meaning and values that can be applied to organize, manage, and control life. These meaning and value motivate researchers to study the use of pemaliq in forest and mountain environments through reviewing forms of pemaliq which are taboo or prohibited, both in the form of words and actions.

\section{Materials and Methods}

Pemaliq data used in the forest environment by the Bayan community, North Lombok, West Nusa Tenggara, Indonesia, is in the form of data of language that is prohibited to be used or the language used to prohibit someone from acting. In the meantime, the data was collected by applying in-depth interview methods and participatory observation.

Data gathered were analyzed by applying ethnographic analysis methods, namely domain analysis, taxonomic analysis, component analysis, and analysis of cultural themes (Spradley, 2006: 151-2-265). Domain analysis refers to types of pemaliq in forest environments. Taxonomic analysis relates to the classification of pemaliq in forest and mountain environments based on the type. Component analysis deals with words or expressions of prohibition in each type of pemaliq in forest or mountain environment and cultural meaning hidden in every word or expression of prohibition. Analysis of cultural themes relates to values that can be applied develop noble behavior or morals. 


\section{Theoretical Framework}

The study of Pemaliq used in the forest environment by the Sasak Bayan community, in North Lombok, West Nusa Tenggara, Indonesia is inseparable from the views of anthropologists, namely Boas concerning about cultural relativism contains the view that language can describe an individual's personal experience of the world of culture (see Foley, 1997: 194--195; Leavitt, 2006: 56). In this case, pemaliq is a medium of psychological or mental expression to build and understand the real world or reality (see Sapir, 1921: 75). In other words, the use of language in pemaliq stores the worldview of the speakers (Worf in Duranti, 1997: 58). However, what needs to be realized is that language differences in the use of pemaliq can describe different worldviews because differences in language can influence one's mind or perception in viewing reality (Leavitt, 2006: 65).

Foley also confirms linguistics anthropology as the study of interpretation that examines language as a basic way to discover the meaning of a culture (Foley, 1997:3; 2016:251). In this case, the view of Foley is in line with Duranti (1997:2) stressing that linguistic anthropology is a study of language as the study of language as a cultural resource and speaking as a cultural practice.

Referring to the views above, a study of pemaliq in this article deals with the use of language (speech use) as a cultural practice with the application of anthropological linguistic theory since pemaliq is in line with the standard of this theory examining the role of language in social and cultural contexts (Foley, 1997: 3 and see also Danesi, 2004: 7; Crystal, 2008: 27; Sibarani, 2014: 314; and compare it to Salzman et al., 2012: 14--25). Foley also stressed that anthropological linguistics as a discipline of interpretation that explores language as an initial step to discover the meaning of a culture (Foley, 1997: 3; 2016: 251). In this case, Foley views breath with Duranti (1997: 2) which emphasizes that linguistic anthropology or anthropological linguistics is the study of language as a cultural source and speaking or speaking as a cultural practice (study as a cultural resource and speaking as a cultural practice)

Language as a cultural source describes pemaliq as a culture creating knowledge embedded in the human mind and knowledge that can only be explored through language (Duranti, 1997: 27; see also Brown, 2006: 96). Meanwhile, language as a practice of speaking describes that pemaliq is used in a social action or the interaction of speech participants who represent ways of thinking or conceptualizing the existence of human and the world (Duranti, 1997: 5). It means that the use of language in pemaliq is only as a symbolic representation that describes the views of the speakers. In the meantime, the use of language in pemaliq as a cultural practice in social interaction is basically a process of building cultural meaning (Foley, 1997: 15). The meaning built on the use of language in pemaliq is a meaning that is public meaning that the meaning is not in the mind the individual so it does not need to be reconstructed because the meaning is basically symbolized in behavior and speech (Geert, 1973: 10-12).

In the application of the study, a study of linguistic anthropology focuses on three aspects, namely (1) performance, (2) indexicality, and (3) participation (Duranti, 1997: 14). In the performance aspect, language is viewed as a process of communicative activities, actions, and performances, which requires creativity. Indexicality aspects are applied to linguistic expressions such as demonstrative pronouns, personal pronouns, temporal expressions, and spatial expressions. Furthermore, the participation aspect views language as a social activity involving speakers and listeners as social actors.

Besides these three aspects proposed by (Duranti, 1997: 14), Sibarani (2015: 97) also stresses that linguistics anthropology has three study parameters serving as guidelines in analyzing language as a source of culture and language as a practice of speaking, namely (1) interconnection, (2) value ability, and (3) sustainability. Parameters of interconnection are related to linear and formal relations of language. A formal relation of language relates to the structure of language or text with context and context. Meanwhile, the linear relation of language relates to structures such as performance structures, grammar, phrase constituent structures, context rules, and rules of contextual distribution (Syarifaturrahman \& Hanafi, 2017). The parameter of value ability refers to the meaning or function, value and norm. Furthermore, the parameter of sustainability emphasizes the state of the object under study including cultural values, local wisdom, and inheritance to the next generation (Alkapitani, 2017; Wirawan, 2018).

Suliadi, -, Laksana, I. K. D., Mahyuni, -, \& Simpen, I. W. (2018). Pemaliq in forest and mountain of sasak community. International Journal of Social Sciences and Humanities, 2(3), 45-55. https://doi.org/10.29332/ijssh.v2n3.195 


\section{Results and Discussions}

Pemaliq used in the forest environment by the Bayan community, North Lombok, West Nusa Tenggara, Indonesia in the form of words or speech and action. In this study, the two types of pemaliq will be discussed concerning on words forbidden to say and expressions used to prohibit someone from acting. In other words, this study continues to focus on the phenomenon of the performance of the use of language practiced by the Bayan community in the form of an expression of prohibition.

\subsection{Pemaliq Okat 'Words or Spoken'}

Pemaliq in the forest and mountain environment in the form of words used by the Bayan community is a prohibition for someone to say or produce certain words when they are in a forest or mountain environment. The words are forbidden to say namely the words belonging to the meaning of the phrase menggoaq bangsa "calling or mentioning the caste" and in the meaning of the phrase ngaranin sesato 'naming animals'.

Menggoaq bangsa is a phrase consisting of the words menggoaq (calling or mentioning) and bangsa (caste). The word menggoaq is categorized as a verb and functions as a predicate. While the word bangsa is categorized as a noun and functions as an object. Furthermore, the word menggoaq itself is morphologically formed on the prefix $\{\mathrm{meN}-\}+$ goaq 'call' $\rightarrow$ menggoaq 'call'. Therefore, the structure of pemaliq menggoaq bangsa is menggoat 'to call or to mention' (V / P) + bangsa 'caste' (N / O) $\rightarrow$ menggoa bangsa literally means calling caste.

Pemaliq menggoaq bangsa for the Sasak Bayan community is a prohibition to call someone who has the status of a social class based on caste, such as Datu, Raden, and or Mamiq. The three castes, when they are in a forest or mountain environment, are strictly prohibited from mentioning, either by someone who is caste himself or by someone else who calls or greets people who have the caste. Prohibition or prohibition to greet someone in a forest or mountain environment by mentioning the three castes can be listened to in the example of the following prohibition statement.

\section{(1) Soraq kanggo ng-goaq bangsa mun tama gawah}

NEG-boleh DA-panggil kasta kalau masuk hutan

'do not call or mention the caste when you are in the forest'

The prohibition above shows that it is not permissible for someone to call the name caste when entering a forest or mountain or when they are in the forest. The prohibition on calling the nation 'caste or nobility' illustrates that the Sasak Bayan community has a particular view of the forest or mountain environment. The Bayan people believe that before the people from the Datu, Raden, and Lalu caste enter the forest or mountain, there is a gegenten 'the person who firstly come or enter the forest or mountain environment'. Therefore, this is the right thing that should be upheld by the caste. In this case, gegenten 'the person who firstly come or enter the forest or mountain environment' is called in metaphors in the form of endocentric phrases, namely Amaq Beleq 'the big man'. In the meantime, when someone enters a forest or mountain with castes of Datu, Raden, and Lalu, the call of this castes must be replaced by the use of metaphor Amaq beleq 'the big man'. This is done to respect and protect the good name of the person who first enters the forest or mountain.

As for someone who violates the pemaliq, there will be a pemastu 'consequence', namely the plague for those who call caste besides the phrase of metaphor amaq beleq ' thebig man' or for someone from the Datu, Raden, and Lalu castes who are proud to be called or addressed by the designation of the noble when in the forest or mountain. In this case, the plague will be received, which is the word kesapan. The word kesapan is morphologically structured confix $\{\mathrm{ke}-\mathrm{i}\}+$ greet $\rightarrow$ kesapaan (greeting) meaning literal kesambet (be seized with a sudden illness). In this case, kesapan is felt in the form of a painful 'fever'.

The existence of the plague received by the violator of pemaliq above is a form of trust of the Bayan community, that the spirit of the ancestors, namely the amaq beleq 'the big man' as a gegenten 'the person who firstly come or enter the forest or mountain environment' will feel himself underestimated or demeaned by newcomers in a forest or mountain that boasts a castle. In this case, the spirit of the ancestors, the Amaq beleq 
' the big man', is a person or thing that begs God to give a warning to someone who prides himself on his rank or cast.

Pemaliq menggoaq bangsa basically stores the meaning and value instilled by the toaq lokaq 'elder people or figure' of the Sasak Bayan community. The meaning implanted is anyone who has merit and has given instructions or a way for others for the good of his or her life, both from officials and ordinary people should be given a reward. In other words, the reward is not based on the class, caste, and position that someone holds. However, someone from any group or caste, when they have contributed to others and especially to the general public, should be respected and appreciated. Therefore, the value that can be applied to the use of pemaliq menggoaq bangs namely (1) respect, that is if they want to be respected and appreciated by others, then respect and appreciate others first; and (2) humility, namely do not boast of class, position and caste in front of people with lower caste or class because it is possible that people who are not in high class or status, not as officials, and not caste have high advantages, both moral superiority, excess knowledge, and other advantages than people who have social class, position, and high caste do.

Furthermore, pemaliq ngaranin sesato is a phrase consisting of the words ngaranin and sesato. The word ngaranin is morphologically formed based on the nasal fix $\{$ ng-i + aran $\rightarrow$ ngaranin 'naming'. Therefore, pemaliq in the phrase ngaranin sesato has the structure of ngaranin 'naming' + sesato 'animal' $\rightarrow$ ngaranin sesato whose literal meaning is naming animals. Meanwhile, based on the context, pemaliq ngaranin sesato 'naming animals' is a prohibition for penjeran 'hunters' who want to menjeran 'catch' animals in the forest to say certain words, namely forbidden to name animals. In this case, animals forbidden to be named are fourlegged animals that are not forested, such as cattle, goats, buffaloes, and horses. These four animals are usually used as jeluq 'dish' for takilan 'rice wrapped in banana leaves' by the panjeran 'hunter'. The prohibition on naming jeluq 'dish' with the names of the four animals is stated in the prohibition statement below.

(2) Soraq kanggo ny-(s)ebut aran sesato siq jari jeluq takilan NEG boleh DA-sebut nama hewan REL. menjadi lauk bingkisan 'do not call or name animals that becomes the dish of (rice wrapped in banana leaves)'

The prohibition on naming jeluq 'dish' using the four animals mentioned above is based on the Sasak Bayan community's belief that the four said animals will bring things that are not profitable for penjeran ' the hunter' such as not getting animal hunted, be getting heavy rain and strong winds suddenly. In this case, the Sasak Bayan community believes that the mention of the names of these animals will be heard by hunted animals and cause the hunted animals to feel that they are not chosen and feel unappreciated by the hunter so that the hunted animals go away from the hunted place. In other words, the hunted animals feel disappointed because the hunter prefers other animals that are not in the forest so the hunted animals will "beg" the Lord Owner of the Universe to bring disaster to the hunter and beg to not get the hunted animals.

As the effort to overcome obstacles of hunting in the forest, as in the phenomenon described above, ancestors have produced certain words in the form of endocentric phrases - attributes as a substitute metaphor for the names of four animals, namely cattle, goats, buffaloes and horses as jeluq 'dish'. In the meantime, if the meat that becomes jeluq 'dish', namely beef, buffalo, and horse must be methylated with manang lènjang 'long legs', while if the ones become jeluq 'dishes' when menjeran 'hunting', namely mutton, then it must be metaphorically marked with jojak lendang 'toys of yard '. In this case, the use of these two metaphors is to replace four animals (cows, buffaloes, horses and goats) with the aim of boasting or glorifying the physical characteristics or characteristics possessed by the hunted animals so that when it is heard by the animals hunted, such as deer or other animals, the animals dare to get close to the hunting trap. In other words, these two metaphors make the hunted animals feel themselves favored and praised by hunters so that they want to approach and want to be friendly with hunters.

Pemaliq ngaranin sesato 'naming animals' means whatever the nature of all the contents of nature, both in the form of physical and behavioral nature, it is a gift from God. Therefore, all God's creations (plants, animals, and humans) have a natural sense to want to be called or addressed with a praising greeting so that it will bring a pulse of pleasure to those who are addressed. In other words, animals, plants, and humans must be greeted with good words or proud words so that they do not cause offense. It means that a person may not greet fellow creatures of God with dirty words that are degrading to nature or behavior possessed by animals,

Suliadi, -, Laksana, I. K. D., Mahyuni, -, \& Simpen, I. W. (2018). Pemaliq in forest and mountain of sasak community. International Journal of Social Sciences and Humanities, 2(3), 45-55. https://doi.org/10.29332/ijssh.v2n3.195 
plants, and humans. In the meantime, pemaliq ngaranin sesato 'naming animals' has values that can be applied to social life, namely (1) polite, refers to calling or greeting someone well and subtly with feeling; and (2) be careful relates to choosing words that are not degrading and offensive to those who are addressed.

\subsection{Pemaliq Pegawean 'action'}

Pemaliq pegawean 'action' in a forest or mountain environment is a prohibition produced by the ancestors of the Sasak Bayan community as an effort to reduce actions or behavior that can harm and endanger themselves, others, other creatures, and nature. The pemaliq pegawean 'action implemented by the Sasak Bayan community can be in the form of phrases and words. Pemaliq pegawean 'action' in the form of phrases such as merebang kayuq 'cutting down trees', membait kayuq 'taking wood', while pemaliq pegawean 'action' in the form of words such as nyelonong 'without permission'. For more details, these prohibition or restrictions are described below.

Merebang kayuq is a pemaliq consisting of two words, that is merebang (cutting down) and kayuq (wood). The word merebang is a word that is categorized as a verb $(\mathrm{V})$ which functions as a predicate $(\mathrm{P})$, while the word kayuq is a noun $(\mathrm{N})$ which functions as an object $(\mathrm{O})$. The word merebang "cutting down" morphologically has a structure, namely the "prefix $\{\mathrm{me}-\}+$ rebang 'to cut' $\rightarrow$ collapses 'cutting down'. Therefore, pemaliq merebang kayuq is formed by the structure merebang (cuttng down) (V / P) + kayuq 'wood tree' $(\mathrm{N} / \mathrm{O}) \rightarrow$ cutting down the wood whose literal meaning is cutting down trees.

Pemaliq merebang kayuq 'cutting down the tree' is a prohibition for people or community to cut down the trees in the forest such as in pawing 'customary forest' since it will cause and trigger the danger and bad influencesor effects not only for people who break the prohibition but also for others, other creatures, and nature. The prohibition to cut the trees in the forest or mountain made by the ancestors of Sasak Bayan community is pictured in the expression of prohibition as follows:

(3) uah rebang kayuq seangen-angen, laun gitaq sita ketemahan

NEG Ømenebang pohon semau-mau, nanti lihat 2SG akibatnya

'don't cut the trees as you want or carelessly, you will see the effect"

The expression of pemaliq above illustrates that if someone cuts down a tree carelessly at the pawang 'customary forest', he or she will accept the temah 'impact' that is the plague of his actions. The plague received by someone who violates the pemaliq can be panas ngeriq 'fever' and paleng 'fainting'. Tulah (plague, fever and fainting) experienced by someone who violates the pemaliq will be felt for days and months and even 'die' if they do not immediately ask for keluputan 'apologizing for the redeemer' by coming to the elders such as shaman 'and brought lekoq buaq' a piece of betel vine and areca nut' 'and asked for help from the shaman to ask God for forgiveness.

The variety of tulah (plagues) suffered by someone who violates pemaliq above is a belief of the Sasak Bayan community towards bakeq 'spirits or mystical thing like ghost' who live in the forest or inhabit large woods in the forest. In this case, the people of Sasak Bayan believe that when someone cuts trees in the forest carelessly, he or she also damaged the house of bakeq 'spirits or mystical thing like ghost', the felled trees can even be used as a place to live for bakeq 'spirits or mystical thing like ghost'. In this case, the Sasak Bayan community believes that the bakeq 'spirits or mystical thing like ghost' whose homes are destroyed will beraq 'anger' so that they are often referred to in terms of the phrase bakeq beraq which means 'angry spirits' who will excite 'begging' to God to punish someone who has ruined their residence. Thus, the plague experienced by someone who cuts trees in the forest is a direct rebuke from God.

As for the meaning embedded in the expression pemaliq merebang kayuq above, the forest is a protector of springs that will give life to other creatures of God. Therefore, trees in the forest must not be cut down or logged wildly so that the water remains durable and no drought will cause difficulties for humans and other creatures (animals and plants) to get water as a staple. In the language of the Sasak Bayan community, drought is often expressed by the expression of ungkapan goro gumi langit 'dry earth and sky'. Goro 'drought' goro on the earth is caused by deforestation and goro 'drought' on the sky illustrates that the gawah 'forest' is unable to attract the sympathy of gulem 'cloud' to approach and decorate it. In addition, the expression 
pemaliq rebang kayuq in the forest or mountain has a specific purpose that there will be no landslides that will cause misery for humans and other creatures.

The expression pemaliq merebang kayuq 'cutting down trees' above also contains values that can be applied in managing human social life, namely (1) tolerance, that is humans do not only maintain good relations with others, but also maintain relationships with other creatures, both with animals, plants and supernatural beings; (2) be careful refers to the existence of caution in cutting wood in the forest to not damage other wood that is not cut; (3) not greedy such as not cutting down forests wildly, but choosing and cutting down wood as needed so that it does not cause drought; (4) responsibility means someone who cuts wood in the forest should plant another wood as a substitute for the woodcut; and (5) care for the environment means having concern in maintaining and preserving the environment, especially forests as a source of water and fresh air.

Furthermore, pemaliq membait kayuq consists of two words, namely membait and kayuq. The word membait (to take) is categorized as a verb (V) and functions as a predicate (P), while the word kayuq (wood) is a noun $(\mathrm{N})$ which functions as an object $(\mathrm{O})$. The word membait itself has a morphological structure, namely the prefix $\{\mathrm{mem}\}+$ bait 'take' $\rightarrow$ membait 'to take'. Therefore, pemaliq membait kayuq is formed by structure membait to'take' (V / P) + kayuq 'wood or tree' $\rightarrow$ membait (to take) which literally means to take a tree. However, based on the context, pemaliq membait kayuq is a prohibition for someone to take branches of wood that fall from the tree or take fallen wood that has died to be brought home and used as gerege 'firewood'. Prohibition of taking wood in the forest is reflected in the expression of prohibition produced by the ancestors as follows.

(4) Soraq kanggo m-bait kayuq siq geran atau siq rebah

NEG-boleh DA-ambil kayu REL. Øjatuh atau REL. Øtumbang

kon pawang

PREP hutan

'Tidak boleh mengambil kayu yang jatuh atau tumbang di hutan'

The expression of the prohibition on taking wood above illustrates the hidden intentions instilled by the Sasak Bayan community ancestors as the creator of pemaliq. The prohibition represents the belief of the Sasak Bayan community that there will be an impact on both someone who violates the forest and the forest tself especially pawang 'customary forest'. For someone who violates it will be plagued for their action. They will feel pain in the part of the body that is used to carry wood taken from the forest, for example, wood was taken and brought home by placing it on the shoulder, then the shoulder will feel pain. Likewise, if the wood is taken from the forest and taken home by placing it on the head, then a person's head will feel pain and heat.

The existence of the plague experienced by pemaliq violators above illustrates the concept of understanding of the Sasak Bayan community that the branches of wood falling from the tree or the wood that collapsed by itself in the forest are the property of small animals that take food provided by fallen wood. In addition, the branches of wood that fall from the tree or fallen wood will automatically become the property of the earth or the land where the wood grows. In this case, fallen dead wood or wood branches that fall by themselves will become humus which can fertilize the soil so that the wood in the forest will flourish. Therefore, if someone takes wood in the forest to be used as firewood, then the small animals and the land where the wood grows in the forest will feel their rights taken so that they (the land and small animals) menunas 'begging' to God to give the punishment to someone who carried away their rights. Therefore, punishment in the form of plague, such as pain and fever experienced by the violator of pemaliq above is a punishment given by God because he or she has taken away the blessings of God given to other creatures.

The expression of pemaliq above essentially has religious and social meaning that is taking the rights of others is a sin and will be rewarded by God. In addition, taking the rights of others is an action that triggers the disharmony of the lives of human beings such as the presence of resentment and hostility. In the meantime, the expression of pemaliq above has the values that can be applied in human life, namely (1) wisdom refers to having an awareness of personal rights and the rights of others; (2) critical knowledge relates to having knowledge of the benefits of something for others; and (3) be grateful or thankful is to be grateful for the blessings that God has given without looking at the magnitude of the blessings and not taking away the blessings given by God to others.

Suliadi, -, Laksana, I. K. D., Mahyuni, -, \& Simpen, I. W. (2018). Pemaliq in forest and mountain of sasak community. International Journal of Social Sciences and Humanities, 2(3), 45-55. https://doi.org/10.29332/ijssh.v2n3.195 
Finally, pemaliq becoming prohibition for someone when they want to enter the forest or mountain, is nyelonong 'without permission'. In this case, a person is strictly prohibited from entering the forest or mountain without asking permission in advance, namely asking permission from creatures in the forest or mountain. The prohibition on nyelonong 'without permission' entering forest or mountain can be seen in the following prohibition.

(5) Uah sita pada sok tama gawah, agir dek ketemuq

NEG 3PLR tiba-tiba Ømasuk hutan, supaya NEG bertemu

'Jangan kalian tiba-tiba masuk hutan, supaya tidak bertemu'

The expression of pemaliq above is basically applicable to anyone, both for children and adults. This can be understood by the use of plural third person pronouns that is confiscation of 'you'. In addition, the expression pemaliq above illustrates the concept of trust produced by the ancestors of the Sasak Bayan community, the belief that there is a danger that befalls when entering gawah 'forest' by means of 'without permission'. This trust can be understood from the word ketemuq. The word ketemuq is morphologically structured as confix $\{\mathrm{ke}-\mathrm{q}\}+$ temu (to mee) $\rightarrow$ ketemuq (meeting). However, based on the contest of the use, ketemuq means the pemaliq violator will meet and be met with the calamity that is the distress that befell the consequences of his or indecent or unconditional behavior to all the contents of the forest. In this case, all the contents of the forest, such as wood, animals, and bakeq that live in the forest feel themselves being overtaken and unappreciated so that they beg God to give a reprimand or punishment to someone who fights 'without permission'.

The consequences experienced by someone who violates the expression of pemaliq nyelonong 'without permission' above can be in the form of pusa 'lost'. In this case, someone who violates will get lost in the forest such as not knowing the way home even for days just around in a place that has been passed by. In other words, one does not find a way out of the forest. In the meantime, the danger of pemaliq is greatly avoided by someone who will enter the forest. Therefore, as an effort to avoid this danger, the ancestors produced expressions of excuse for all the contents of the forest as a form of respect as fellow creatures of God, namely the tabeq selapuq isin gawah, ku meliwat 'excuse me all that live in this forest, I am passing'.

The expression of asking permission above illustrates that someone entering the forest is considered to be the person who is going to visit. In this case, as a person who visits, he or she must show manners or courtesy so that those who have a home are not offended and demeaned. Therefore, the expression of permission above can be said as someone's warning or greeting to forest dwellers, both to wood, animals, and bakeq 'spirits'. This greeting will make all forest dwellers feel happy because they are respected and appreciated.

The meaning that can be constructed from the expression pemaliq nyelonong 'without permission' above is that all of God's creation, both the visible and the invisible all want to be respected and appreciated. Therefore, in the expression of pemaliq there are values that can be applied in living, managing and controlling human life including (1) the value of respect, referring to respect for fellow human beings and other fellow beings so as to create peace and tranquility; (2) being humble, that is not having an arrogant attitude, not feeling the best and not feeling the most perfect; (3) be vigilant, namely having caution in building communication with others so that no one feels offended; and (4) awareness, which is aware that in this world humans do not live alone, but live side by side with other creatures created by God, both visible and invisible.

\section{Conclusion}

Based on the discussion in section IV above, it can be concluded that the use of pemaliq in the forest and mountain environment by the Sasak Bayan community in North Lombok, West Nusa Tenggara, Indonesia, illustrates the views of the Sasak Bayan community towards vague forces that can interfere and endanger human life. In the meantime, the ancestors produced their own rules as an effort to curb and protect themselves from the dangers that would befall them by producing restrictions or prohibition for themselves and for members of indigenous peoples. In addition, the use of pemaliq in forest and mountain environments illustrates the prudence and neatness of the words and attitudes of the ancestors and members of the Sasak Bayan community in living their lives. 
The pemaliq produced by the ancestors of the Sasak Bayan community in forest and mountain environments consists of pemaliq okat 'words' and pemaliq pegawean 'actions'. Pemaliq okat 'words' that is abstinence or prohibition of saying certain words, namely (1) menggoaq bangsa 'calling caste or prominent noble', for example caste Datu, Raden, and Lalu or Mamiq; and (2) ngaranin sesato 'naming animals', for example by using the names of cows, goats, buffaloes, and horses. Violation of these two pemaliq will cause a danger to plague the violator. Therefore, to avoid the danger of plague, the ancestors produced certain words as substitutes for words that were forbidden to say, such as metaphors of attribute phrases, namely amaq beleq ' the big man' pemaliq menggoaq bangsa 'calling caste' and the metaphor of the attributes of the lame attribute manang lènjang 'long legs' and jojak lendang 'toys of yard' for pemaliq ngaranin sesato. Meanwhile, pemaliq pegawean 'action', the prohibition to act arbitrarily in the forest and mountain environment consists of three types, namely pemaliq in the form of phrases (1) merebang kayuq 'cutting down trees', (2) membait kayuq 'taking wood' , and (3) the form of the word, which is nyelonong 'without permission'.

Pemaliq produced in the forest and mountain environment by the Sasak Bayan ancestors basically stores noble meanings and values. Thes Pemaliq produced is rich in magical meaning, religious meaning, and social meaning. Furthermore, the values embedded in the use of the expression pemaliq in forest and mountain environments can be implemented in living life, including (1) respect; (2) be careful or alert; (3) polite; (4) humble; (5) tolerant; (6) responsible; (7) not greedy; (8) care for the environment; (9) awareness; (10) wisdom; (11) critical knowledge; and (12) thankful.

\section{Acknowledgments}

In this article, the author would like to thank the supervisors for their criticism and suggestions, as well as their invaluable ideas are woven so that this short writing becomes more perfect.

Suliadi, -, Laksana, I. K. D., Mahyuni, -, \& Simpen, I. W. (2018). Pemaliq in forest and mountain of sasak community. International Journal of Social Sciences and Humanities, 2(3), 45-55. 


\section{References}

Alessandro, D. (1997). Linguistic anthropology. Cambridge Textbooks in Linguistics.

Alkapitani, M. (2017). The enrichment of new vocabularies in Sasak language because of gold mining spreading in Sekotong west Lombok. International Journal of Social Sciences and Humanities (IJSSH), 1(3), 182-193.

Crystal, D. (2011). A dictionary of linguistics and phonetics(Vol. 30). John Wiley \& Sons.

Danesi, M. (Ed.). (2004). A basic course in anthropological linguistics (Vol. 2). Canadian Scholars Press.

Edward, S. (1921). Language: An introduction to the study of speech. Journal of Women s Health.

Foley, W. A. (2012). Anthropological linguistics. The Encyclopedia of Applied Linguistics.

Freud, S., \& Brill, A. A. (2001). Three contributions to the theory of sex. Courier Corporation.

Geertz, C. (1973). The interpretation of cultures (Vol. 5043). Basic books.

Jourdan, C., \& Tuite, K. (Eds.). (2006). Language, culture, and society: Key topics in linguistic anthropology (Vol. 23). Cambridge University Press.

Leavitt, J. (2006). "Linguistic Relativities”. Dalam Jourdan, Christine \& Tuite, Kevin, editor. Language, Culture, and Society: Key Topics in Linguistic Anthropology. Cumbridge, dll.,: Cambridge University Press.

Salzmann, Z., Stanlaw, J., \& Adachi, N. (2014). Language, culture, and society: An introduction to linguistic anthropology. Westview Press.

Sibarani, R. (2012). Kearifan Lokal: Hakikat, Peran, dan Metode Tradisi Lisan. Asosiasi Tradisi Lisan (ATL).

Sibarani, R. (2015). Pembentukan Karakter Langkah-langkah Berbasis Kearifan Lokal. Jakarta: Asosiasi Tradisi Lisan.

Spradley, J. P. (1997). Metode Etnografi, terj. Misbah Zulfa Elizabeth, Tiara Wacana, Yogyakarta. Cet I.

Syarifaturrahman, W. K., \& Hanafi, N. (2017). The Inflection of Sasak Language in Kuripan Village. International Journal of Social Sciences and Humanities (IJSSH), 1(3), 155-181.

Wirawan, I. W. A. (2018). Maintaining Social Relationship of Balinese and Sasak Ethnic Community. International Journal of Social Sciences and Humanities (IJSSH), 2(1), 92-104.

Worf, R. C. (2007). The Case for Rational Basis Review of General Suspicionless Searches and Seizures. Touro L. Rev., 23, 93. 


\section{Biography of Author}

\begin{tabular}{|l|l||}
\hline \hline & $\begin{array}{l}\text { Suliadi was born in Rangsot, Juli 05, 1986. He is a doctorate student. He lives at } \\
\text { Sanggar Sari, Sigar Penjalin Village, District of Tanjung, North Lombok, West Nusa } \\
\text { Tenggara, Indonesia. He graduated his bachelor degree from Indonesian Language } \\
\text { Education, Hamzanwadi University, Selong, East Lombok 2013. He finished his } \\
\text { Master of Indonesian Language Education from Mataram University, 2016. He } \\
\text { currently studies at Udayana University to earn his doctoral degree of Linguistics. } \\
\text { Email: suliadiabet@yahoo.com }\end{array}$ \\
\hline
\end{tabular}

Suliadi, -, Laksana, I. K. D., Mahyuni, -, \& Simpen, I. W. (2018). Pemaliq in forest and mountain of sasak community. International Journal of Social Sciences and Humanities, 2(3), 45-55. https://doi.org/10.29332/ijssh.v2n3.195 